University of Massachusetts Amherst

ScholarWorks@UMass Amherst

Masters Theses 1911 - February 2014

1982

\title{
Effects of hysterectomy on sexual receptivity, food intake, running wheel activity, and hypothalamic estrogen and progestin receptors in rats.
}

Harry Ahdieh

University of Massachusetts Amherst

Follow this and additional works at: https://scholarworks.umass.edu/theses

Ahdieh, Harry, "Effects of hysterectomy on sexual receptivity, food intake, running wheel activity, and hypothalamic estrogen and progestin receptors in rats." (1982). Masters Theses 1911 - February 2014. 1276.

https://doi.org/10.7275/75f4-fc94

This thesis is brought to you for free and open access by ScholarWorks@UMass Amherst. It has been accepted for inclusion in Masters Theses 1911 - February 2014 by an authorized administrator of ScholarWorks@UMass Amherst. For more information, please contact scholarworks@library.umass.edu. 
EFFECTS OF HYSTERECTOMY ON SEXUAL RECEPTIVITY, FOOD INTAKE, RUNNING WHEEL ACTIVITY, AND HYPOTHALAMIC ESTROGEN AND PROGESTIN RECEPTORS IN RATS

A Thesis Presented

By

HARRY AHDIEH

Submitted to the Graduate School of the University of Massachusetts in partial fulfillment

of the requirements for the degree of MASTER OF SCIENCE

February 1982

Department of Psychology 


\section{EFFECTS OF HYSTERECTOMY ON SEXUAL RECEPTIVITY, FOOD INTAKE, RUNNING WHEEL ACTIVITY, AND HYPOTHALAMIC ESTROGEN \\ AND PROGESTIN RECEPTORS IN RATS}

\section{A Thesis Presented}

By

HARRY AHDIEH

Approved as to style and content by:
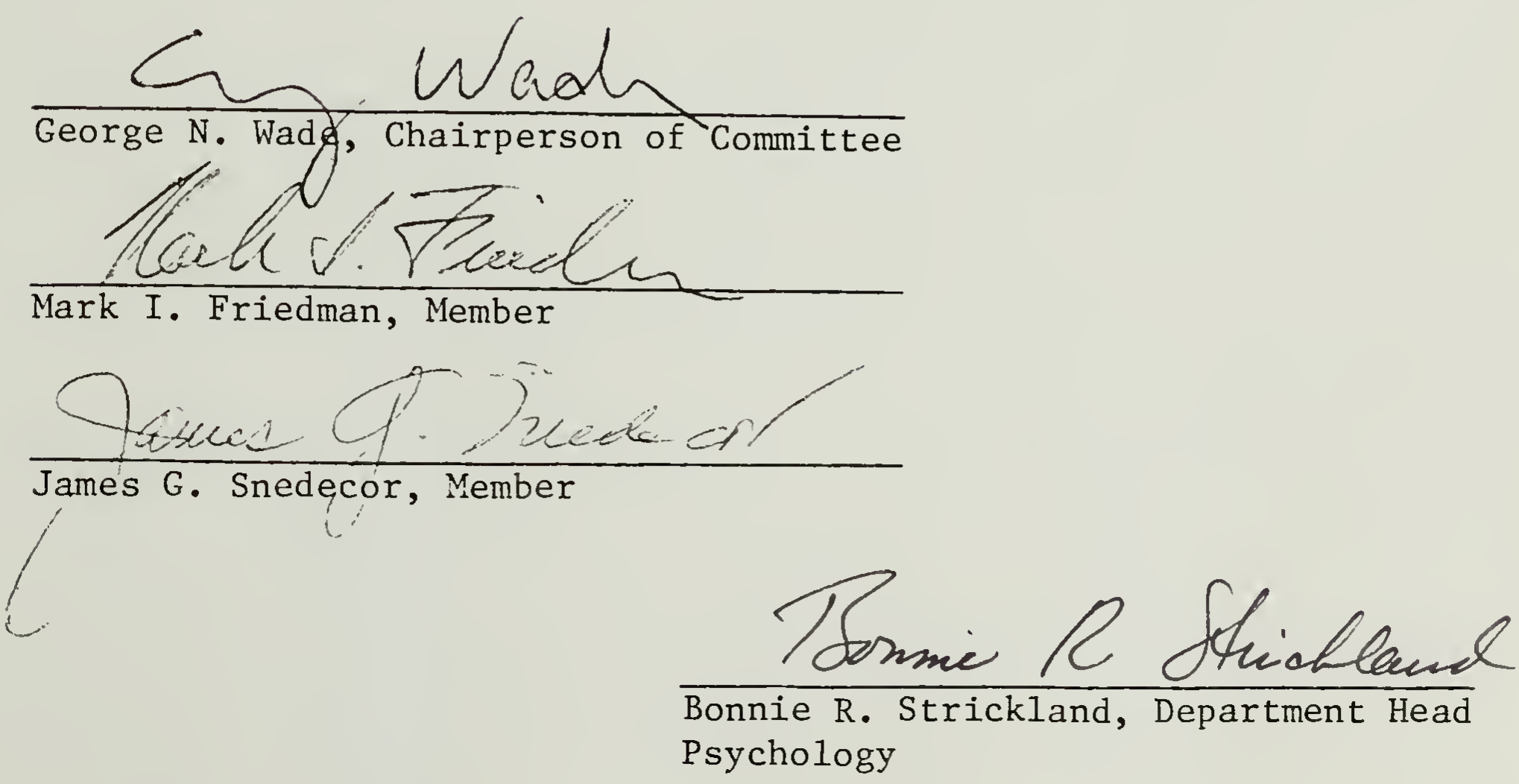


\section{ACKNOWLEDGEMENTS}

I would like to thank the members of my thesis committee, George Wade, Mark Friedman and James Snedecore for their careful review of my thesis and for all the helpful suggestions from which I learned a lot. I am particularly grateful to my advisor, George Wade, who welcomed my research ideas enthusiastically and assisted me, both in thought and practice, in examining relevant hypotheses and made clear to me the distinction between "explicitness" and "implicitness" in presentation of the results of these studies.

I wish to thank Harold Siegel of the Institute of Animal Behavior (Rutgers University) who helped me learn about the field of hormones and behavior, and whose ideas initiated my interest in pursuing the present research.

I thank Suzi Schwartz and Lindi Siegel who helped me with the unattractive labor of brain dissections, especially when it was scheduled at 8:00 A.M. and Joy Littlejohn and Jay Alexander for their assistance with surgery. 


\section{ABSTRACT}

Effects of Hysterectomy on Sexual Receptivity, Food Intake, Running Wheel Activity, and Hypothalamic Estrogen and Progestin Receptors in Rats

February 1982

Harry Ahdieh, B.A., University of Bridgeport M.A., University of Massachusetts Directed by: George N. Wade

The effects of hysterectomy on several hormone-dependent behaviors and on neural estrogen and progestin receptors were studied in a series of experiments in rats. Ovariectomized-hysterectomized $(\mathrm{OH})$ rats given sequential treatments with $2 \mu \mathrm{g}$ estradiol benzoate $(E B)$ and $.5 \mathrm{mg}$ progesterone (P) showed significantly higher lordosis quotients than ovariectomized (OV) rats in two tests, one and two weeks after surgery. To test whether the effects of hysterectomy persist, 3 groups of $\mathrm{OV}$ and $\mathrm{OH}$ rats received weekly injections of $\mathrm{EB}$, EB plus $P$, or sesame oil vehicle for 4 weeks, were then given $2 \mu g$ EB followed $24 \mathrm{hr}$ later by $.5 \mathrm{mg} \mathrm{P}$ and tested for receptivity. Only the $\mathrm{OH}$ animals that had received hormone treatments for 4 weeks showed a significantly higher lordosis score than OV animals. The effects of hysterectomy on food intake, body weight gain and running wheel activity were also tested. After one week of $2 \mu \mathrm{g} \mathrm{EB} /$ day treatment, $\mathrm{OH}$ rats lost significantly more weight and consumed less food than 
OV rats, but by two weeks, the effects of hysterectomy were no longer evident. Treatment of animals with $.5 \mathrm{\mu g} \mathrm{EB} / \mathrm{day}$ resulted in significant loss in body weight and food intake of $\mathrm{OH}$ animals throughout the experiment. Similarly, $\mathrm{OH}$ animals implanted with silastic capsules containing $E B$ were significantly more active in running wheels than OV animals over the first 9 days, but by day 23 , the activity of both groups were similar. Twenty four hr following a single injection of EB, hypothalamic-preoptic area cell nuclear estrogen and cytoplasmic progestin receptors were significantly higher in $\mathrm{OH}$ rats than in OV rats. Some of the possible mechanisms by which hysterectomy acts to enhance hormone-dependent behaviors are discussed. 
ACKNOWLEDGEMENT. • . . . . . . . . . . . . . . . . . . . iii ABSTRACT • • • • . . . . . . . . . . . . . . . . . iv LIST OF FIGURES. . . . . . . . . . . . . . . . . . . vii INTRODUCTION . . . . . . . . . . . . . . . . . . 1

Ovarian hormones and sexual receptivity. . . . . . . . . . 3

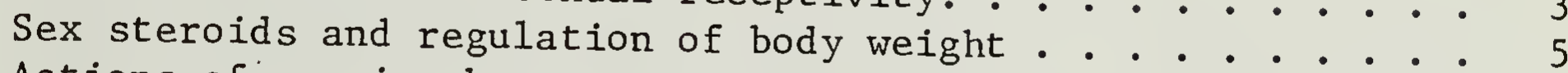

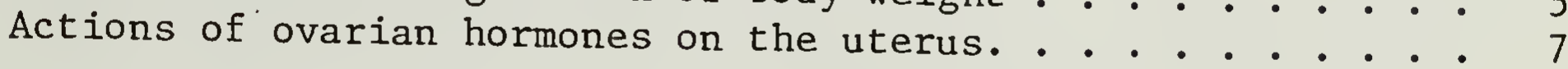

Experiment 1: Lordosis. . . . . . . . . . . . . . . . 9

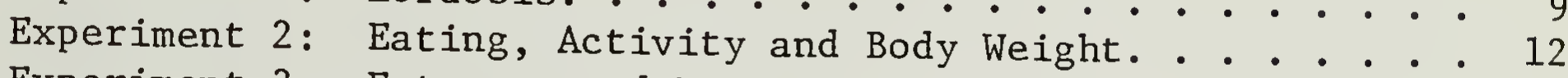

Experiment 3: Estrogen and Progestin Receptors. . . . . . . . 16 DISCUSSION . . . . . . . . . . . . . . . . . 19 REFERENCES . . . . . . . . . . . . . . . . . . . 24 


\section{LIST OF FIGURES}

1. Effects of Hysterectomy on Lordosis . . . . . . . . . . . . . 11

2. Effects of Hysterectomy on Lordosis After Periodic Hormone Treatment . . . . . . . . . . 13

3. Changes in Food Intake and Body Weight Gain as a Function of Hysterectomy. . . . . . . . . . . . . 15

4. Changes in Running Wheel Activity as a Function of Hysterectomy •. • • • • • • • • • • • • . . . 17

5. Effects of Hysterectomy on Brain Cell Nuclear Estrogen and Cytoplasmic Progestin Receptors . . . . . . . . 20 


\section{INTRODUCTION}

Both ovarian and testicular steroids affect a wide variety of behaviors in mammals. Reproductive behaviors such as courtship, copulation and parental behavior have been studied most extensively, and a direct relationship has been established between these behaviors and the circulating gonadal hormones. Behaviors such as locomotor activity and food intake are also regulated by gonadal hormones. In estrous-cycling rats, sequential secretion of estradiol and progesterone induce sexual receptivity. Estradiol also causes an elevation in voluntary activity and a decrease in food intake and body weight at estrus.. On the other hand, progesterone acts both synergistically with estradiol to induce an optimum display of sexual behavior, and antagonistically to inhibit receptivity. An increase in food intake and body weight has been associated with high plasma progesterone titers.

On a molecular level, the effects of estradiol and progesterone seem to follow a classical steroid hormone action on target tissue model. This model suggests that the steroids secreted by the ovaries, testes, and the adrenals are carried in the circulation to various tissues where they passively diffuse into the cells. In the target tissues, the steroid molecules are bound by high-affinity, hormonespecific cytoplasmic receptor proteins. The hormone-receptor 
complexes are then translocated to the cell nucleus where they become associated with some component of chromatin. These complexes alter the rate of synthesis of specific mRNA molecules. The mRNA molecules are then transported to the cytoplasm where they control protein synthesis. The new proteins mediate the tissues' physiological responses. According to this model, target tissues should exhibit high-affinity, hormone-specific cytoplasmic binding sites (receptors), and selective subcellular hormone concentration in cell nuclei (Gorski \& Gannon, 1976; 0'Malley \& Means, 1974).

Hypothalamus is one potential target site for sex hormone actions. The hypothalamus contains cytoplasmic estrogen (Eisenfeld, 1970; Eisenfeld \& Axelrod, 1965), progestin (Maclusky \& McEwen, 1978), and androgen (Barley, Ginsburg, Greenstein, Maclusky \& Thomas, 1975) receptors. Treatment of ovariectomized rats with behaviorally effective doses of estradiol benzoate (EB) or progesterone causes nuclear translocation of cytoplasmic estrogen and progestin receptors in the hypothalamus. Within an hour of hormone injection, cytoplasmic receptors are depleted and brain cell nuclear concentrations are elevated (Lieberburg \& McEwen, 1977; Zigmond \& McEwen, 1970; Blaustein \& Wade, 1978).

Although the ovarian steroids selectively bind to many regions of hypothalamus, it appears that the most effective sites for the induction of behavioral responses are in medial basal and preoptic areas of hypothalamus (Zigmond \& McEwen, 1970). Sexual receptivity can be induced most effectively by intracerebral implants of estradiol 
and progesterone in ventromedial hypothalamus (Davis, McEwen \& Pfaff, 1981; Rubin \& Barfield, 1981). Similarly, implants of estradiol in ventromedial hypothalamus decrease food intake, and implants in the medial preoptic area increase running wheel activity (Wade \& Zucker, 1970).

Ovarian hormones and sexual receptivity. In female rodents, sexual receptivity follows a cyclic pattern. For example, rats and hamsters are receptive once every 4-5 days, while guinea pigs reach this stage every 15-16 days. Estrous behavior is induced by the sequential secretion of estradiol and progesterone by the preovulatory ovaries in these rodents. In estrous cycling rats, the blood level of estradiol begins to rise about two days prior to the onset of estrous behavior, and there is a sharp peak in ovarian progesterone secretion approximately 6 hours before sexual receptivity occurs. Estrous behavior is abolished by ovariectomy, but receptivity can be restored by treatment with estradiol and progesterone (Beach, 1948; Young, 1961).

Estradiol alone is sufficient for induction of mating in ovariectomized female rats, because the injection of daily doses in the range of 1 to $10 \mu \mathrm{g}$ allows them to show lordosis in a high proportion of mounts they receive (Davidson, Rogers \& Smith, 1968; Pfaff, 1970). Progesterone, on the other hand, is not necessary for the expression of sexual receptivity, but when given $24-48$ hours after estradiol, this behavioral response is further facilitated. This facilitation by progesterone may take the form of increasing the percentage of animals 
that are behaviorally responsive, decreasing the latency of response to a fixed dose of estradiol, or permitting a decrease in the dosage of required estradiol (Morin \& Feder, 1973; Whalen, 1974).

Progesterone may also act to inhibit the expression of sexual behavior. When ovariectomized rats or guinea pigs are concurrently treated with estradiol and high doses of progesterone, little or no lordosis behavior is displayed (Edwards, Whalen \& Nadler, 1968). Furthermore, the facilitatory effects of additional progesterone given 24-48 hours later are not manifested or are diminished. This dose-dependent inhibitory effect of progesterone can be demonstrated in intact and ovariectomized animals; for example, at certain stages of pregnancy, rats are resistant to the induction of lordosis by sequential estrogen and progesterone treatment (Powers \& Zucker, 1969). Although this resistance is initiated at times of high levels of progesterone secretion, indicating an inhibitory role for induction of sexual receptivity (Powers \& Moreines, 1976), recent studies suggest that this refractoriness may not be due to progesterone (DeGreef, Schenck, Vreeburg, Van Der Voart \& Baum, 1981).

Another inhibitory effect of progesterone is the post-estrous refractoriness that occurs in intact guinea pigs after they have exhibited lordosis under the influence of their own hormonal secretion (Young, 1969). During this time, it is difficult to elicit lordosis by injecting estradiol and progesterone. Evidence indicates that the same progesterone that first facilitated the expression of lordosis, causes a transitory period of refractoriness to further hormonal 
stimulation (Zucker, 1968). Progesterone does not inhibit brain cell nuclear binding of $\left({ }^{3} \mathrm{H}\right)$-estradiol (Blaustein \& Wade, 1977; DeBold, Martin \& Whalen, 1976), or inhibit the replenishment of estrogen receptors after an injection of estradiol (Pavlik \& Coulson, 1976), nor does it compete for brain estrogen receptors (Walters \& Clark, 1978; Freifeld, Feil \& Bardin, 1974).

The fact that estrogen-inducible progestin receptors can be measured in the brain, permits an approach to the problem of subcellular mechanisms of the action of progesterone in the establishment of behavioral refractoriness to further progesterone treatment. Work with uterine tissue indicates that after progesterone depletes cytoplasmic progestin receptors and causes the translocation of receptors to the uterine cell nuclei, the cytoplasmic progestin receptors are not replenished (Leavitt, Toft, Strott \& O'Malley, 1974; Walters \& Clark, 1978). Other studies show that in fact there is a significant possibility that this phenomenon occurs in the central nervous system (Blaustein \& Feder, 1979; Moguilewsky \& Raynaud, 1979) and may account for the post-estrous refractoriness.

Sex steroids and regulation of body weight. Body weight and adiposity fluctuate dramatically during changes in reproductive conditions in rats, and these fluctuations in body weight and more strikingly in adiposity are mainly due to changes in circulating titers of ovarian or testicular steroids.

Ovariectomy causes an increase of $20-25 \%$ in body weight in female rats, and this increase can be reversed or prevented by treatment 
with estradiol (Wade, 1976). Treatment of ovariectomized rats with progesterone has no effect on body weight, but administration of progesterone to ovariectomized estrogen-primed or gonadally intact rats leads to an increase in body weight (Wade, 1976).

These changes in body weight and adiposity are accompanied by fluctuations in food intake and running wheel activity. It has been widely assumed that gonadal hormones act directly on the brain to influence these regulatory behaviors, which in turn determine body weight. Recent findings, however, indicate that in addition to possible central effects, estradiol and progesterone may modulate food intake by acting directly on the peripheral sites to alter metabolism. While gonadal hormone receptors have been demonstrated to exist in such organs as liver or pancreas, much work has been done on adipose tissue because of its role as an energy storage depot and as a determinant of the availability of circulating metabolic fuel. Investigators have demonstrated that steroids are taken up by adipose tissues in several mammalian species (Bleau, Roberts, \& Chapdelaini, 1974). In addition to their capacity to store these triglyceride-soluble steroids, adipose tissues have been shown to contain specific, high-affinity binding sites for estradiol (Wade \& Gray, 1978), and high-affinity, estrogen-inducible cytoplasmic progestin receptors (Gray \& Wade, 1979). Furthermore, estradiol treatment lowers adipose tissue lipoprotein lipase (LPL) activity (Hamosh \& Hamosh, 1975). Lipoprotein lipase is a limiting factor in the transport of circulating triglycerides into adipose storage depots (Scow, Hamosh, Blanchette-Mackie \& Evans, 
1972). Changes in LPL activity are closely correlated with steroid induced changes in food intake, body weight and adiposity (Wade \& Gray, 1979).

Actions of ovarian hormones on the uterus. Estrogens initiate cyclic preparations of the uterine lining (endometrium) for implantations by promoting hyperemia, more rapid uptake of water, electolytes and small organic molecules, and stimulation of synthesis of RNA and proteins. Both epithelial and stromal components of endometrium proliferate rapidly by mitosis, uterine glands elongate and tissues are primed for the subsequent action of progesterone. Estrogensalso promotes growth and strengthening of myometrium (Greep, 1973).

Progesterone acts on the estrogen primed endometrium to complete preparation for implantation. With the release of increasing amounts of progesterone, there appears to be a wave of hyperplasia involving all tissues, particularly the smooth muscle cells. In at least some species, progesterone hyperpolarizes cell membranes of myometrium, promoting relaxation and preventing coordinated contraction (Greep, 1973).

Considerable evidence suggests that the actions of estradiol and progesterone on uterus are mediated through binding with cytoplasmic macromolecule receptors within uterine cells and translocation of steroid-receptor complex to the nucleus (Shyamala \& Gorski, 1969; Fianopoulous \& Gorski, 1971; Walters \& Clark, 1977; Feil \& Bardin; 1975). Indeed, studies with in vivo and in vitro binding of radioactive estradiol have shown that the concentration of specific 
binding of estradiol in uterus is many fold greater than in pituitary or hypothalamus (Eisenfeld, 1970; Cidlowski \& Muldoon, 1974). Systemic administration of radiolabeled R5020, a synthetic progestin, to estrogen primed female rats results in the specific binding of the steroid with the whole homogenate and cell nuclei of uterus as well as pituitary and some brain regions (Blaustein \& Wade, 1978). Similar to the pattern of the binding of estradiol, the uptake of R5020 seems to be greater in the uterus than in the pituitary or the brain (Blaustein \& Wade, 1978). These findings indicate that uterus is a major target organ for the actions of estradiol and progesterone through specific binding sites or receptors, and that these receptors are likely to mediate the physiological responses of uterus to these hormones.

The purpose of this thesis is to investigate the role of uterus in modulating the effects of estradiol and progesterone on sexual receptivity, food intake, and running wheel activity, all of which are influenced by the availability and concentration of ovarian hormones in the circulatory system. Studies have shown that hysterectomy significantly enhances the onset of maternal behavior in ovariectomized, estrogen primed, nulliparous rats (Siegel \& Rosenblatt, 1975). Furthermore, ovariectomized-hysterectomized rats treated with estradiol benzoate (EB) and progesterone (P) show significantly higher lordosis quotients than ovariectomized animals (Siegel, Ahdieh \& Rosenblatt, 1978). In the following studies, I have extended this work by examining; 1) the time-course of the effects of hysterectomy on 
lordosis, 2) the effects of hysterectomy on EB-induced changes in food intake, running wheel activity and body weight gain, and 3) the effects of hysterectomy on levels of cell nuclear estrogen receptors and cytoplasmic progestin receptors in hypothalamus-preoptic area of EB-treated rats.

\section{Experiment 1: Lordosis}

Siegel, Ahdieh and Rosenblatt (1978) showed that hysterectomy facilitates EB-plus-P-induced lordosis in rats. Part 1 of this experiment attempts to replicate this finding. Siegel and Rosenblatt (1975) also found that hysterectomy enhances the onset of maternal behavior in rats when it is followed immediately by a period of estradiol treatment but not when the hormone is given 8 weeks after surgery. Part 2 examines the time-course and hormone-dependency of the effects of hysterectomy on lordosis.

Method.

Subjects. Female CD-strain rats weighing 200-250 g (Charles River Breeding Laboratories, Wilmington, Massachusetts) were housed individually and maintained on a 12-hr light, 12-hr dark (lights on at $2400 \mathrm{hr}$ ) photoperiod. The animals were given Purina rodent chow and tap water ad libitum.

Surgery. Ovariectomy and hysterectomy were done using a single midventral incision under methoxyflurane (Metofane; Pitman-Moore, Washington Crossing, New Jersey) anesthesia.

Lordosis testing. Experimental tests consisted of placing 
several sexually active male rats in a $75 \mathrm{~cm}$ diameter $\times 25 \mathrm{~cm}$ high testing arena with a wood chip-covered floor under dim illumination provided by a $25-W$ red bulb during the dark phase of the 1ight-dark cycle. The males remained in the arena for 1-2 hr prior to the introduction of the female. Each female was tested until she received 10 vigorous mounts with thrusting. Lordosis quotients (LQ, lordosis per mount times 100) were computed. Data were analyzed using $\underline{t}$-tests and considered statistically significant if $\underline{p}<.05$.

Hormone treatment. In all parts of the first experiment, each rat received $2 \mu \mathrm{g} E B$ subcutaneously, and, where necessary, followed $24 \mathrm{hr}$ later by $.5 \mathrm{mg} \mathrm{P}$. Sexual receptivity was tested $4 \mathrm{hr}$ following P treatment.

\section{$\underline{\text { Part } 1}$}

Procedure. Ovariectomized (OV) and ovariectomized-hysterectomized (OH) animals $(\underline{n}=10$, each group) received EB followed $24 \mathrm{hr}$ later by $\mathrm{P}$ and were tested one week postoperatively. They were then given the same hormone treatment a week later and tested again.

Results. Ovariectomized-hysterectomized animals displayed significantly higher LQs than OV animals in both tests $(\underline{t}(18)=2.41$, $\mathrm{p}<.05$ in the first test, and $\underline{\mathrm{t}}(18)=2.66, \underline{\mathrm{p}}<.02$ in the second test), and there was no significant change from the first test to the second (Fig. 1).

Part 2.

Procedure. To test whether the effect of hysterectomy persists, 
$\mathrm{OV}$ and $\mathrm{OH}$ rats were divided into 3 groups $(\underline{n}=10$ each $)$. Starting one week after surgery, the first group was given $2 \mu \mathrm{g}$ EB once a week for 4 weeks. The second group received the same treatment with the addition of $.5 \mathrm{mg} P 24 \mathrm{hr}$ after each EB injection. The animals in the third group were given sesame oil injections on the same schedule. One week after the fourth set of injections, all animals received $2 \mu \mathrm{g} E B$ and $.5 \mathrm{mg} \mathrm{P}$ and were tested for estrous behavior.

Resuits. Ovariectomized-hysterectomized rats which received weekly injections of EB or EB plus P had significantly higher lordosis scores than OV rats $(\underline{t}(18)=3.06, \underline{p}<.01$ and $\underline{t}(18)=2.38, \underline{p}<.05$ respectively), but scores of oil-treated $\mathrm{OV}$ and $\mathrm{OH}$ groups did not differ significantly (Fig. 2).

Experiment 2: Eating, Activity and Body Weight

In rats, gonadal hormones influence behaviors such as food intake and running wheel activity which in turn influence body weight. This correlation is clear in estrous-cycling rats where food consumption and activity fluctuate with the cycle (Kennedy \& Mitra, 1963). Ovariectomy decreases running wheel activity and increases food intake and body weight. Estradiol replacement reverses the effects of ovariectomy (Mook, Kennedy, Roberts \& Rodier, 1972; Wade, 1976). Since hysterectomy was shown to enhance the hormone-dependent sexual receptivity, food intake and running wheel activity were examined to determine whether similar effects exist.

Part 1: Food Intake and Body Weight 
CHANGES IN FOOD INTAKE AND BODY WEIGHT GAIN AS A FUNCTION OF HYSTERECTOMY
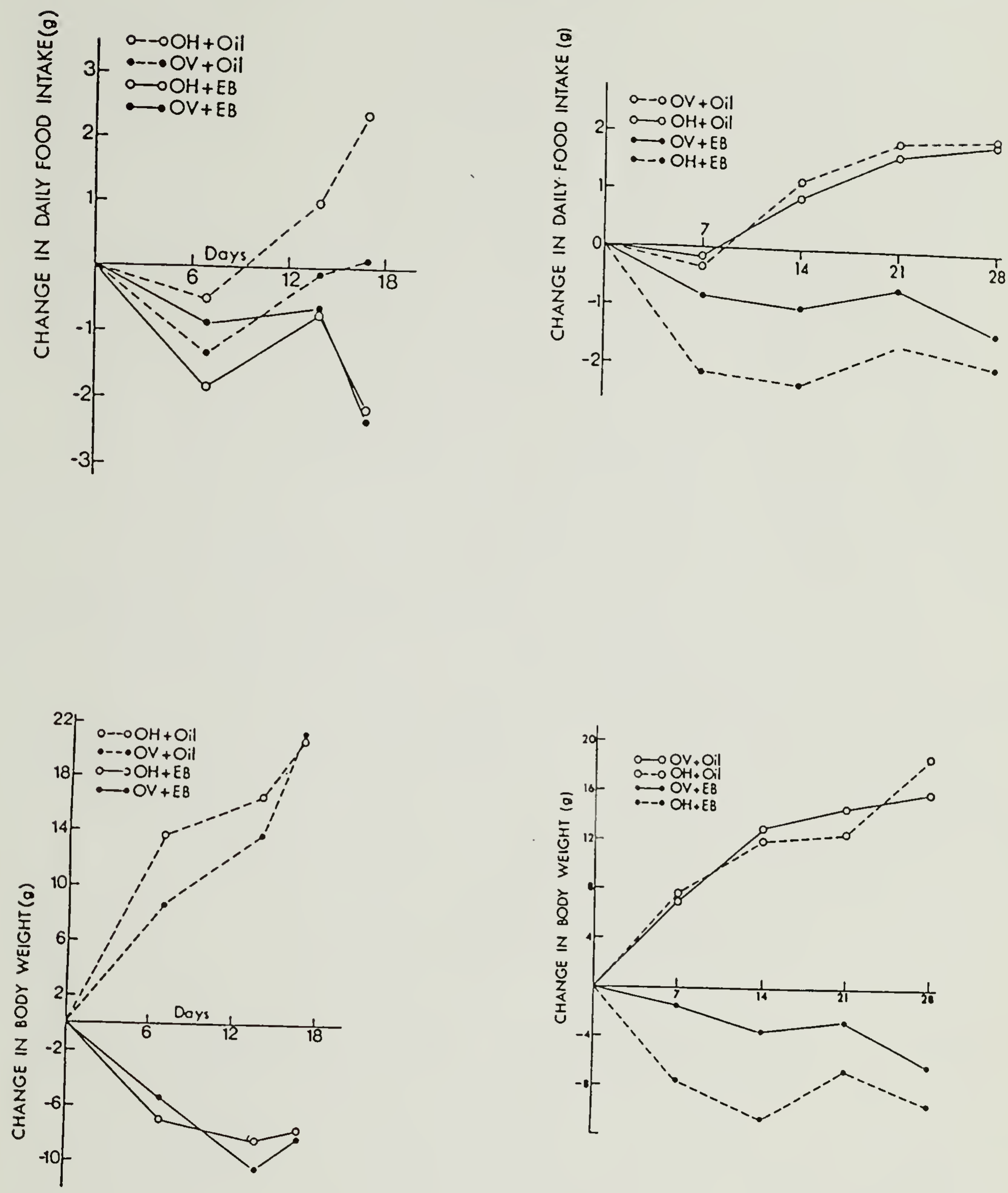

Figure 3. Food intake and body weight gain of $\mathrm{OV}$ and $\mathrm{OH}$ rats treated for 18 days with $2 \mu \mathrm{g} /$ day of EB or oil (upper graphs), and 21 days with $.5 \mathrm{\mu g} /$ day of $\mathrm{EB}$ or oil (lower graphs). 
Procedure. Starting 3 weeks following surgery, OV and $\mathrm{OH}$ rats were divided into 2 groups $(\underline{\mathrm{n}}=10$ for hormone treatment and $\underline{\mathrm{n}}=7$ for oil vehicle treatment in each group) and given daily injections of $2 \mu \mathrm{g} E B$ or sesame oil for 18 days. The experiment was then repeated with different rats which received $.5 \mathrm{\mu g}$ EB or oil per day for 28 days. Food intake (to the nearest $.1 \mathrm{~g}$, including spillage) and body weight (to the nearest $g$ ) were measured 3 times a week.

Results. Ovariectomized-hysterectomized rats treated with $2 \mu \mathrm{g}$ $E B$ per day lost significantly more weight, relative to the oiltreated controls, than OV rats after one week of $E B$ treatment $(E(2,18)$ $=3.61$, Bonferroni $\underline{t}=2.98, \underline{p}<.05)$, but after 2 weeks and thereafter, the effects of hysterectomy were no longer evident (Fig. 3). Similarly, EB treatment decreased food intake more in the OH rats than in OV rats over the first 7 days of treatment $(\underline{F}(2,18)=3.81$, Bonferroni $\underline{t}=3.17, \underline{p}<.05)$ but not thereafter.

The $\mathrm{OH}$ animals which received $.5 \mu \mathrm{g} \mathrm{EB} /$ day, however, lost more weight $(\underline{F}(1,27)=4.55, \underline{P}<.05)$ and consumed less food $(\underline{F}(1,27)=$ 4.36, $\mathrm{p}<.05$ ) than OV animals throughout the treatment period (Fig. 3).

Part 2: Running Wheel Activity.

Procedure. Intact female rats were placed in activity cages (Wahmann Manufacturing Co., Timonium, Maryland), and baseline activity was measured over 14 days. Prior to surgery, $\mathrm{OV}$ and $\mathrm{OH}$ animals were matched for baseline activity (OV $\overline{\mathrm{X}}=4569$ revolutions/day; OH $\overline{\mathrm{X}}=$ 4417 revolutions/day). They were then ovariectomized or ovariectomized- 
hysterectomized and received silastic capsules, $15 \mathrm{~mm} / 100 \mathrm{~g}$ body weight, containing $E B$ in sesame oil $(166 \mu \mathrm{g} / \mathrm{ml})$. Running wheel activity was recorded 3 times a week for 5 weeks.

Results. Running wheel activity was expressed as percent change in activity from the baseline. Over the first 9 days, ov animals reduced activity while $\mathrm{OH}$ animals showed a considerable increase in activity with a significant difference between the 2 groups over the first 9 days $(\underline{F}(2,28)=3.96$, Bonferroni $\underline{t}=3.14, \underline{p}<.05)$. Both groups increased their activity from day 10 to day 23 and decreased it thereafter (Fig. 4).

The pattern of the change in activity as a function of hysterectomy was similar to that of food intake and body weight gain of the animals which received $2 \mu \mathrm{g}$ EB per day. It appears that in both cases, hysterectomy was effective in modulating behavior within the first several days of treatment when relatively high doses of EB were used. The effects subsided thereafter.

Experiment 3: Estrogen and Progestin Receptors

Considerable evidence suggests that responses to estradiol and progesterone are mediated through binding of these molecules with specific cytoplasmic receptors and translocation of steroid-receptor complex to the cell nuclei (Gorski \& Gannon, 1976; 0'Ma11ey \& Means, 1974). Furthermore, cytoplasmic progestin receptors are induced by estradio1 (Maclusky \& McEwen, 1978; Moguilewsky \& Raynaud, 1979). The extent of the effects of these hormones depends on both 
cytoplasmic receptor concentration and on nuclear translocation (McEwen, Davis, Parsons \& Pfaff, 1979). In this experiment, the effects of hysterectomy on hypothalamic cell nuclear estrogen and cytoplasmic progestin receptors were examined.

Part 1: Brain cell nuclear estrogen receptors.

Procedure. Twenty $\mathrm{OV}$ and $20 \mathrm{OH}$ rats were divided into 2 groups $(\underline{n}=10$ each) which were given $2 \mu \mathrm{g} \mathrm{EB}$ or oil and killed $24 \mathrm{hr}$ later with an overdose of Nembutal. They were perfused through the heart with cold .15 M NaCl. Hypothalamus and preoptic area were dissected and pooled prior to homogenization. Cell nuclei were isolated from the homogenized tissues by the method of Zigmond and McEwen (1970). The levels of estrogen receptors in cell nuclei were determined by the exchange assay of Roy and McEwen (1977). Cell nuclear estrogen receptors were solubilized by dispersing the nuclei in TBD buffer (10 mM Tris-HCl, $1 \mathrm{mM}$ dithiothreitol, .5 mM bactracin, $\mathrm{pH} \mathrm{7.6)} \mathrm{and}$ then adding equal volume of TBDK .8 (TBD, $.8 \mathrm{M} \mathrm{KCL).} \mathrm{Samples} \mathrm{were}$ incubated at $0^{\circ} \mathrm{C}$ for 30 minutes and were centrifuged at $16,000 \mathrm{X} \mathrm{g}$ for 10 minutes. Aliquots of supernatant containing solubilized estrogen receptors were incubated with $5 \mathrm{mM}\left({ }^{3} \mathrm{H}\right)$ estradiol (specific activity; $91.8 \mathrm{Ci} / \mathrm{nmol}$, New England Nuclear) with or without $1 \mu \mathrm{M}$ radioinert estradiol for 4 hr at $25^{\circ}$ C. Bound and free $\left({ }^{3} \mathrm{H}\right)$ estradiol were separated by gel filtration on 5 X $60 \mathrm{~mm}$ Sephadex LH-20 columns. Nuclear pellets were dissolved in $.3 \mathrm{~N} \mathrm{KOH}$, and DNA content was determined by the method of Burton (1965). Specific binding was calculated as total binding minus nonspecific binding. Results are 
presented as femtomoles estradiol bound per mg DNA.

\section{Part 2: Cytoplasmic progestin receptors}

Procedure. Twenty $\mathrm{OV}$ and $20 \mathrm{OH}$ rats were divided into 2 groups $(\underline{n}=10$ each) which received $2 \mu \mathrm{g}$ EB or oil and were killed $24 \mathrm{hr}$ later. Cytoplasmic progestin receptors in pooled hypothalamus-preoptic area were assayed according to the method of Blaustein and Feder (1979). Tissues were homogenized at a concentration of $100 \mathrm{mg} /$ ml TEGM buffer (10 mM Tris-HCl, $1.5 \mathrm{mM}$ EDTA, 10\% glycerol, and $12 \mathrm{mM}$ monothioglycerol, $\mathrm{pH}, 7.4)$. After centrifugation at 48,000 X $\mathrm{g}$ for 1 $\mathrm{hr}, 350-\mu \mathrm{g}$ aliquots of supernatant were incubated with $.4 \mathrm{nM}\left({ }^{3} \mathrm{H}\right) \mathrm{R} 5020$ (specific activity; $86 \mathrm{Ci} / \mathrm{mmol}$; New England Nuclear) with or without

$4 \times 10^{-8} \mathrm{M}$ radioinert $\mathrm{R} 5020$ for $4 \mathrm{hr}$ at $0^{\circ} \mathrm{C}$. Bound and free $\left({ }^{3} \mathrm{H}\right) \mathrm{R} 5020$ were separated by gel filtration on 5 X $60 \mathrm{~mm}$ Sephadex LH-20 columns. Supernatant protein concentration was determined by the method of Lowrey et al. (1951). Data are presented as femtomoles R5020 specifically bound per mg protein.

Results. Cell nuclear estrogen and cytoplasmic progestin receptors were significantly higher in EB-treated than in oil treated animals (Fig. 5). Furthermore, there was a greater level of cell nuclear estrogen receptors $(\underline{t}(18)=2.38, \underline{p}<.05)$ and induction of progestin receptors $(\underline{F}(1,17)=5.87, \underline{\mathrm{p}}<.05)$ in the OH rats than in the ov rats.

\section{DISCUSSION}

These findings confirm the previous studies which examined the 
effects of hysterectomy on estrous behavior, and extend it to other hormone-dependent behaviors. Experiment I repiicated the work of Siegel et al. (1978) showing that hysterectomy enhances the facilitation of lordosis behavior by estradiol and progesterone. Furthermore, the results of part 2 indicated that as with maternal behavior (Siegel \& Rosenblatt, 1975), the effects of hysterectomy on lordosis wane with time if periodic estradiol stimulation is absent. Ovariectomized and $\mathrm{OH}$ rats which received oil injections for a month prior to $E B$ plus $P$ treatment were equally receptive whereas $O V$ and $O H$ rats pretreated weekly with EB or EB plus $P$ were significantly different.

Experiment 2 extended these findings to two other estrogen-dependent behaviors, eating and running wheel activity. Apparently, the prolonged continuous treatment of $\mathrm{OV}$ and $\mathrm{OH}$ animals with high levels of $E B$ results in an initial difference in food intake, body weight, and running wheel activity, followed by similar responses thereafter, whereas the facilitative effects of hysterectomy persist in animals given a lower dose of EB. The high doses of EB may render the action(s) of uterus ineffective or may mask them, whereas treatment with low doses could either keep the uterus active or delay the waning of its effects.

It is not clear how uterus inhibits the estrogen-dependent behaviors. There are at least two-not-mutually-exclusive possibilities: 1) The uterus could lower circulating estradiol titers by either taking up significant amounts of the hormone (larger estradiolstimulated uterus would have greater capacity than atropied uterus), 
or by enhancing metabolism of circulating estradiol to less potent steroids and/or facilitating the clearance of it. Studies show that EB-treated monkeys have significantly greater milk secretion, and serum levels of estradiol and estrone following hysterectomy (Kuo, Cobb, Esber \& Bogden, 1974). 2) The uterus may produce some substance which acts at a distant site to decrease the responses of target tissues to estradiol. Prostaglandins are one possible candidate for this action. Caldwell et al. (1972) showed that estradiol or estradiol and progesterone stimulate the secretion of prostaglandin PGF in the ewe and that hystereciomy abolishes plasma PGF. Recently, DeGreef et al. (1980) examined the Inhibition of lordosis in pregnant rats and suggested that a placental factor may be responsible for the suppression of this behavior. It is possible that the same placental factor or its analog may be secreted by the uterus and account for its inhibitory action.

Finally, Experiment 3 demonstrated that hysterectomy enhances hypothalamic preoptic area cell nuclear estrogen and cytoplasmic progestin receptor levels after EB treatment. This increase in cell nuclear receptor concentration is consistent with the hypothesis that steroid hormones act via cell nucleus to change behavior, and that the extent to which the behavior is expressed is dependent on the level of cell nuclear receptors (McEwen, Davis, Parsons \& Pfaff, 1979). Antiestrogens and diabetes mellitus are factors that have been shown to reduce brain cell nuclear binding and thus lower behavioral responses to estradiol (Roy \& Wade, 1977; Siegel \& Wade, 1979). However, 
hysterectomy is the first demonstration of a treatment that enhances brain cell nuclear estrogen receptors and behavioral responses. Experiment 3 also replicated previous findings that estradiol treatment induces cytoplasmic progestin receptors in the brain (Maclusky \& McEwen, 1978; Moguilewsky \& Raynaud, 1979) and showed that hysterectomy enhances this induction. The elevated levels of cytoplasmic progestin receptors may play an important role in the facilitation of lordosis behavior in $\mathrm{OH}$ rats, since siegel et al. (1978) demonstrated that estradiol and progesterone are both required for the facilitation of sexual receptivity in $\mathrm{OH}$ rats. 


\section{REFERENCES}

Barley, J., Ginsburg, M., Greenstein, B.D., Maclusky, N.J.\& Thomas, P.J. An androgen receptor in rat brain and pituitary. Brain Research, 1975, 100, 383-393.

Beach, F.A. Hormones and Behavior, New York; Cooper Square, 1948. Blaustein, J.D. \& Feder, H.H. Cytoplasmic receptors in guinea pig brain: characteristics and relationships to the induction of sexual behavior. Brain Research, 1979, 169, 481-497.

Blaustein, J.D. \& Feder, H.H. Cytoplasmic progestin receptors in female guinea pig brain and their relationship to refractoriness in expression of female sexual behavior. Brain Research, 1979, $177,489-498$.

Blaustein, J.D. \& Wade, G.N. Progestin binding by brain and pituitary cell nuclei and female rat sexual behavior. Brain Research, 1978, $140,360-367$.

Blaustein, J.D. \& Wade, G.N. Concurrent inhibition of sexual behavior but not brain $\left({ }^{3} \mathrm{H}\right)$ estradiol uptake by progesterone in female rats. Journal of Comparative and Physiological Psychology, 1977, 91 , $742-751$

Bleau, G., Roberts, K.D. \& Chapdelaini, A. The in vivo and in vitro uptake and metabolism of steroids in human adipose tissue. Journal of Clinical Endocrinology and Metabolism, 1974, 29, 236. 
Burton, K. A study of conditions and mechanisms of the diphenylamine reaction for the colorimetric estimation of deoxyribonucleic acid. Biochemistry Journal, $1965,62,315-323$.

Caldwell, B.V. \& Tillson, S.A. The effects of exogenous progesterone and estradiol on prostaglandin F levels in ovariectomized ewes. Prostaglandins, $1972, \underline{1}, 217$.

Cidlowski, J.H. \& Muldoon, T.G. Estrogenic regulation of cytoplasmic receptor populations in estrogen-responsive tissues of the rat. Endocrinology, 1974, 95, 1621.

Davis, P.G., McEwen, B.S. \& Pfaff, D.W. The site of action of intrahypothalamic implants in feminine sexual behavior: an autoradiographic analysis. Paper presented at the Conference on Reproductive Behavior, 1981, Nashville, Tenn.

Davidson, J.M., Rogers, C.H., \& Smith, E.R. Stimulation of female sex behavior in adrenalectomized rats with estrogen alone. Endocrinology, 1968, 82, 193-195.

DeBold, J.F., Martin, J.V. \& Whalen, R.E. The excitation and inhibition of sexual receptivity in female hamsters by progesterone: time and dose relationship, neural localization and mechanisms of action. Endocrinology, 1976,99, 1519-1527.

DeGreef, W.J., Schneck, P.E., Vreebrug, J.T., Van Der Voart, P.D.\& Baum, M.J. Evidence that a placental factor other than androsterone, or dihydrotestosterone inhibits estrogen-induced lordosis behavior in pregnant rats. Journal of Endocrinology, 1980, 89, $13-23$ 
Edwards, D.A., Whalen, R.E. \& Nadler, R.D. Induction of estrous: estrogen-progesterone interactions. Physiology and Behavior, $1968, \underline{3}, 29-33$.

Eisenfeld, A.J. ${ }^{3}$ H-estradiol: in vivo binding to macromolecules from rat hypothalamus, anterior pituitary and uterus. Endocrinology, $1970, \underline{86}, 1313-1326$.

Eisenfeld, A.J. \& Axelrod, A. Selectivity of estrogen distribution in tissues. Journal of Pharmacology and Experimental Therapeutics, $1965, \underline{150}, 469-475$.

Feil, P.D. \& Bardin, C.W. Cytoplasmic and nuclear progesterone receptors in guinea pig uterus. Endocrinology, 1975, 97, 13981407 .

Freifeld, M.L., Feil, P.D. \& Bardin, C.W. The in vivo regulation of progesterone receptor in guinea pig uterus: dependence on estrogen and progesterone. Steroids, 1974, 23, 43-103.

Giannopolous, G. \& Gosski, J. Estrogen receptors: quantitative studies on transfer of estradiol from cytoplasmic to nuclear binding sites. Journal of Biological Chemistry, 1971, 246, 25242529 .

Gorski, G. \& Gannon, F. Current models of steroid hormone action: a critique. Annual Review of Physiology, 1976, 38, 425-450.

Gray, J.M. \& Wade, G.N. Cytoplasmic progestin binding in rat adipose tissue. Endocrinology, 1979, 104, 1377-1382.

Greep, R.0., Volume ed. Female Reproductive System, Part 1 and 2 of Handbook of Physiology, Section 7, Vol. 2. American Physiology 


\section{Society, Washington D.C., 1973.}

Hamosh, M. \& Hamosh, P. The effects of estrogen on the lipoprotein lipase activity of rat adipose tissue. Journal of Clinical Investigation, $1975, \underline{55}, 1132-1135$.

Kennedy, C.C.\& Mitra, J. Hypothalamic control of energy balance and the reproductive cycle in the rat. Journal of Physiology, 1963, $395-407$.

Kuo, E.Y.H., Cobb, W.R., Esber, H.J.\& Bogden, A.E. Effects of hysterectomy on milk secretion and serum levels of prolactin, growth hormone, estrogen and progesterone in rhesus monkeys with hormone induced utering hypertrophy. American Journal of obstetrics and Gynecology, 1974, 120, 368-371.

Leavitt, W.W., Toft, D.O., Strott, C.A.\& O'Malley, B.W. A specific progesterone receptor in the hamster uterus: physiological properties and regulation during the estrous cycle. Endocrinology, 1974, 94, 1041-1053.

Lowry, O.H., Rosebrough, J.N., Farr, A.L.\& Randall, J.R. Protein measurement with the Folin phenol reagent. Journal of Biological Chemistry, 1951, 193, 265-275.

Maclusky, N.J. \& McEwen, B.S. Oestrogen modulates progestin receptor concentrations in some brain regions but not in others. Nature, $1978, \underline{274}, 276-278$.

McEwen, B.S., Davis, P.G., Parsons, B. \& Pfaff, D.W. The brain as a target for steroid hormone action. In M. Cowan (Ed.), Annual Review of Neuroscience, 1979, pp. 65-112. 
Moguilewsky, M. \& Raynaud, J. The relevance of hypothalamic and hypophyseal progestin receptor in the induction and inhibition of sexual behavior in the famale rat. Endocrinology, 1979, 105, $516-522$

Mook, G.D., Kennedy, N.J., Roberts, S., Nussbaum, A.I. \& Rodier, W.I. Ovarian-adrenal interactions in regulation of body weight by female rats. Journal of Comparative and Physiological Psychology, $1972, \underline{81}, 198-211$.

Morin, L.P. \& Feder, H.H. Multiple progesterone injections and the duration of estrus in ovariectomized guinea pigs. Physiology and Behavior, 1973, 5, 157-162.

O'Malley, B.W. \& Means, A.R. Female steroid hormones and target cell nuclei. Science, 1974, 183, 610-620.

Pavlik, E.J. \& Coulson, P.B. Modulation of estrogen receptors in four different target tissues: differential effects of estrogen vs. progesterone. Journal of Steroid Biochemistry, 1976, 7 , 369376 .

Pfaff, D.W. Nature of sex hormone effects on rat sex behavior: specificity of effects and individual pattern of response. Journal of Comparative and Physiological Psychology, 1970, 72, $45-50$

Powers, J.B. \& Morines, J. Progesterone: examination of its postulated inhibitory actions on lordosis during the rat estrous cycle. Physiology and Behavior, 1976, 17, 493-498. 
Powers, J.B. \& Zucker, I. Sexual receptivity in pregnant and pseudopregnant rats. Endocrinology, 1969, 84, 820-827.

Roy, E.J. \& McEwen, B.W. An exchange assay for estrogen receptors in the cell nuclei of adult rat brain. Steroids, 1977, 657669.

Roy, E.J. \& Wade, G.N. Binding of $\left({ }^{3} \mathrm{H}\right)$ estradiol by brain cell nuclei and female rat sexual behavior: inhibition by antiestrogens. Brain Research, $1977, \underline{126}, 73-87$.

Rubin, B.S. \& Barfield, R.J. Site of action of progesterone in the regulation of estrous responsiveness in female rats. Paper presented at the Conference on Reproductive Behavior, Nashville, Tenn., 1981.

Scow, R.0., Hamosh, M., Blanchette-Mackie, E.J., \& Evans, A.J. Uptake of blood triglyceride by various tissues. Lipids, 1972, 7 , 490-505.

Shyamala, G. \& Gorski, J. Estrogen receptors in the rat uterus: studies on the interaction of cytosol and nuclear binding sites. Journal of Biological Chemistry, 1969, 244, 1097-1101.

Siegel, H.I., Ahdieh, H.B. \& Rosenblatt, J.S. Hysterectomy-induced facilitation of lordosis behavior in the rat. Hormones and Behavior, $1978, \underline{11}, 273-278$.

Siegel, H.I. \& Rosenblatt, J.S. Estrogen-induced maternal behavior in ovariectomized-hysterectomized virgin rats. Physiology and Behavior, 1975, 14, 465-471. 
Siegel, L.I. \& Wade, G.N. Insulin withdrawal impairs sexual receptivity and retention of brain cell nuclear estrogen receptors in diabetic rats. Neuroendocrinology, 1979, 29, 73-87.

Wade, G.N. Sex hormones, regulatory behaviors and body weight. In: Advances in the Study of Behavior, Vol. 6, Edited by J.S. Rosenblatt, R.A. Hinde, E. Shaw, \& C.G. Beer. New York: Academic Press, 1976, pp. 201-279.

Wade, G.N. \& Gray, J.M. Gonadal effects on food intake and adiposity: a metabolic hypothesis. Physiology and Behavior, 1979, 22, 583593.

Wade, G.N. \& Gray, J.M. Cytoplasmic $17-\left({ }^{3} \mathrm{H}\right)$ estradiol binding in rat adipose tissue. Endocrinology, 1978, 10, 1695-1701.

Wade, G.N. \& Zucker, I. Modulation of food intake and locomotor activity in female rats by diencephalic hormone implants. Journal of Comparative and Physiological Psychology, 1970, 72, 328-336. Walters, M.R. \& Clark, J.H. Cytosol progesterone receptors of the rat uterus: assay and receptor characteristics. Journal of Steroid Biochemistry, $1977, \underline{8}, 1137-1143$.

Walters, M.R. \& Clark, J.H. Cytosol and nuclear compartmentalization of progesterone receptors in the rat uterus. Endocrinology, 1978, $601-609$.

Whalen, R.E. Estrogen-progesterone induction of mating in female rats. Hormones and Behavior, 1974, 11, 866-871.

Young, W.C. Psychobiology of sexual behavior in guinea pigs. In: Advances in the Study of Behavior. Vol. 2: pp. 1-110, 1969. 
Young, W.C. The hormones and mating behavior. In: Sex and Internal Secretions, W.C. Young, ed. William and Wilkins, Pp. 1173-1239, 1969.

Zigmond, R.E. \& McEwen, B.S. Selective retention of oestradiol by cell nuclei in specific brain regions of the ovariectomized rat. Journal of Neurochemistry, 1970, 17, 889-898.

Zucker, I. Biphasic effects of progesterone on sexual receptivity in the female guinea pig. Journal of Comparative and Physiological Psychology, 1968, 65, 472-478. 


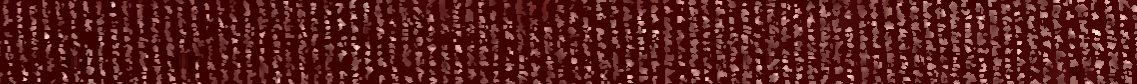

